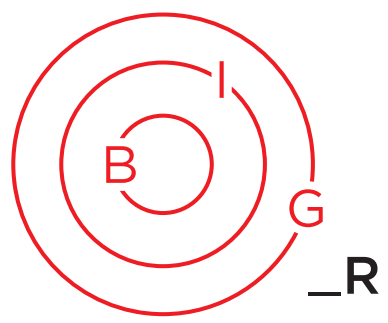

ARTICLE

\title{
Cross-border Life in an American Exclave: Point Roberts and the Canada-US Border
}

\section{Pierre-Alexandre Beylier *}

\begin{abstract}
By applying a theoretical framework based on different models proposed in border studies literature, this article analyzes the morphological, functional, institutional and identity characteristics that make Point Roberts-an American exclave in the Pacific Northwest-a "cross-border town". Using an online survey and face-to-face interviews, the author combines both quantitative and qualitative research methods in order to examine the forces that link Point Roberts and the Canadian city of Delta that lies across the Canada-US border. This paper highlights the specificities of this unique geographic configuration as well the challenges that the border represents.
\end{abstract}

\section{Introduction}

Located in the periphery of countries, border towns were traditionally associated with remoteness and neglect, while assuming a significant military role in the defense of territories. This situation went hand in hand with the use of borders as buffer zones (Sohn \& Lara-Valencia 2013; Herzog 1991; Sparrow 2001, 73). However, borders and border towns have seen their role change in the last 60 years with the advent of globalization combined with the appeasement of territorial tensions, especially in Europe and North America. Border regions have gradually become more integrated in the world economy as a result of the defunctionalization of borders, defined as the removal or the weakening of some of their functions (Pradeau 1994) thus shifting from the periphery to a more central role (Sohn \& Lara-Valencia 2013; Herzog 1991; Sparrow 2001, $3)$. This combination of factors has placed border towns at the crossroads of influence and phenomena (Nugent 2012, 570), making them an interesting lens through which one can study borders and the forces that shape them. In the last two decades, scholars in border studies have focused on border towns, trying to define them and to classify them by type.
Buursink offers a straightforward definition of border town: more than just a town located at the border, it is a town "that is dependent on the border for its existence (...) not just a city located close to the border but it also came into existence because of the border" (Buursink 2001, 7-8). This general definition has been refined by incorporating the origins and the causal relationship between the border and the town and taking into account the border-related forces that shape the town, what Reitel calls a "logic of spatial organization" (Reitel 2002, 125). In other words, it is a town that "lives from the border", that can exploit the discontinuities and that can prosper because of the differentials induced by the border (138).

Many border towns are paired with another town located on the other side of the border with which they have developed very specific links. Whether they are "duplicated" or "partitioned", these "paired cities" or "twin cities" have received extensive attention on the part of border scholars and geographers (Buursink 2001; Kearney 1995; Vanneph 1995; Soi \& Nugent 2017; Jańczak 2017; Ganster \& Collins 2017). These researchers have explored

\footnotetext{
* Pierre-Alexandre Beylier, PhD in North American Studies, Université Grenoble Alpes (ILCEA4).

Email: pierre-alexandre.beylier@univ-grenoble-alpes.fr
} 
cross-border trade and cooperation (Nugent 2012, 559; Vanneph 1995) as well as the way these links give birth to a "functional cross-border space" (Foucher 1991, 421). Ultimately, border towns develop mutual dependence that results from the fact that they "feed off one another in an active sense" and share "mutually-embedded relationships" (Soi \& Nugent 2017). These links shape those urban pairs and translate into more or less formal relations that can become institutionalized, thus giving twin cities a political or administrative framework of governance (Buursink 2001; Ehlers 2001; Jańczak 2017; Ganster \& Collins 2017). Finally, researchers have emphasized the "social base for [town] twinning" (Jańczak 2017): how these specific interactions give birth to specific regional cross-border identities (Bucken Knapp 2001), a sense of "belonging together" (Buursink 2001; Kaisto 2017).

Major cross-border metropolitan areas have come under great scrutiny in Europe-for example, Geneva/Anemasse and Basel/Mulhouse (Reitel 2013), Vienna/Bratislava (Giffinger \& Hamedinger 2013)-and also in North America-for example, Detroit/Windsor (Brunet-Jailly 2000), Vancouver/Seattle (Cold-Ravnkilde et al 2004; Brunet-Jailly 2008). Smaller border towns, however, have not been studied to the same extent. The goal of this paper is to examine a small border town in Washington State: Point Roberts. Even though Point Roberts is a part of Cascadia-a major cross-border region that encompasses Vancouver, Seattle, and surrounding areasexamining the situation of a smaller border town and the local phenomena that shape it can be interesting in order to better understand how border towns function. What makes Point Roberts even more interesting is the fact that, in addition to being a border town, this community is also an exclave. Located on a peninsula, it is only accessible by land through Canada. Exclaves were traditionally described by geographers as a curiosity (Lunden \& Zalamans 2001, 33) but they are more than just oddities and they are by definition even more dependent on and affected by the border.

One of the earliest settlements in the Pacific North West, Point Roberts was founded in 1857 first as a stop for sailors heading north to Alaska, then as a military base and later as a fishing town known for its salmon canneries (Swenson 2017, 102). Over time, this small unincorporated community has been shaped as much by its maritime connections as by the border (ibid).

Geographically speaking, Point Roberts is located across the border from the city of Delta, British Columbia, which is a part of the Greater Vancouver area and is itself comprised of three suburban communities: Tsawwassen, North Delta and Ladner. Point Roberts, with a population of 1,191 and a density of 243 people per square mile (Census Reporter 2020), contrasts with the dense urban unit of Delta with 102,238 inhabitants and 1,469 people per square mile (StatCan 2016). This configuration is special in that it does not form what Buursink calls "paired towns" or "twin towns" (Buursink 2001) and they are rather marked by a great asymmetry in terms of population, density and economic dynamism. And yet, exploring the relationship that Delta and Point Roberts share across the 49th parallel can shed light on how border towns work.

The goal of this paper is to examine the unique spatial configuration that combines an international border and an exclave in order to see if it has led to the emergence of a "new territoriality" (Bucken-Knapp 2001, 55, quoting Smouts 1998). In other words, this paper will study the "binational" dimension of Point Roberts and its cross-border dimension in order to assess the extent of its integration in British Columbia's Lower Mainland in comparison with other border towns in the region. Does its situation as an exclave amplify cross-border integration?

In order to carry out this analysis, this paper will first outline the theoretical framework and methodology then present and discuss data collected through interviews and surveys of residents on both sides of the border.

\section{Theory}

As mentioned in the introduction, a border town cannot be defined only in locational terms: a town at the border. Fuentes underscores the fact that the urban function of a border town is "transformed" by a "transnational relationship" (Fuentes 2000, 21). For Reitel and Zander, it is a town that has developed a specific relationship with the border and thus "presents original configurations in relation with the border's properties" (Reitel \& Zander 2020).

The first relationship has been shaped by the origins of border towns that are often associated with a control function in terms of either defense or customs; traditionally a border town was a stronghold that also served to levy duties (Pradeau 1994; Reitel \& Zander 2020; Renard 2000). The second relationship that shapes border towns has to do with the discontinuity that the border represents and that requires transportation to adapt or that is being exploited in terms of differentials by shoppers, commuters or smugglers. Finally, the third one has to do with the instrumentalization of the border town by the central government as an area of representation and symbolism (Reitel \& Zander 2020). This three-fold definition highlights factors that shape border towns and that contribute to their specificity, but it remains rather general and some authors have tried to find criteria that are more analytical and that can be used as "tests".

The criterion that most scholars underscore is the functional dimension of border towns. In other words, the border town is linked by "functional ties" (Herzog 1990; Gay 2004, 70) with the other side of the border, most of the time another town, whether it is a twin town or a "companion town" (Buursink 2001, 16). These links have to do with the fact that the border is an active interface that fosters cross-border links among residents on both sides 
of the international line, in terms of shopping, tourism, trade, commuting, and other activities. These links are the sign that the two urban units transcend the border to some extent and function together (Foucher 1991, 421; Herzog 1991), giving rise to a "functional region" (Lunden \& Zalamans 2001, 41; Letniowska 2002, 112) or a "crossborder networked space" (Vanneph 1995).

However, this criterion is just one among others, and growing academic interest in border towns has led scholars to propose theoretical models that highlight different criteria. Buursink was one of the first to define "border-crossing cities": "cities that make contact with each other in terms of (1) physical or built-up landscape, (2) institutional framework and (3) the city as a community" (Buursink 2001, 17). These criteria are similar to those put forward by Ehlers: (1) closeness, (1b) size, (2) institutional base and (3) residents (Ehlers 2001, 23, 25). Adapting Buursink's model, Sparrow offered criteria that looked at border towns in terms of integration: (1) physical integration, (2) organizational integration (NGOs and civil society), (2b) political administrative integration, (3) behavioral integration (Sparrow 2001, 82). One can finally mention Gradus' criteria, which are proximity, function that encompasses binational structures and cooperation, and a feeling of closeness (Gradus 2001, 84).

Building on those criteria, Reitel proposes another model that aims at analyzing border towns through the processes that the town is the site of in terms of integration: morphological integration, which has to do with both proximity and the continuity of the urban fabric; functional integration, which concerns the flows of commuters; intentional integration, which is the formulation of a plan for cooperation; and institutional integration, that has to do with cross-border governance and the construction of cross-border institutions. All of them are measured in terms of interactions or what he calls "the level of connectivity of the boundary" (Reitel 2013, 245).

This model is interesting because it applies some of the criteria put forward in the literature of border towns looking at the processes that shape and define them. The difference between intentional integration and institutional integration mirrors the distinction between "formal" and "informal" cooperation that is often highlighted (Ehler 2001, 28; Jańczak 2017, 487). However, a shortcoming of this model pertains to the fact that it does not take identity matters, a criterion highlighted by a number of researchers, into account.

To define border towns, the author will use four criteria, which sum up and combine these models. The first criterion is a (I) morphological one that covers both geographical proximity to the border and the continuity of the urban fabric, in the case of paired towns. The second criterion is (II) a functional one that has to do with the different flows that occur between the border town and the other side of the border and that link them whether in terms of trade, cross-border commuters, cross-border shopping and other cross-border activities. The third criterion concerns (III) cross-border governance and the construction of bilateral institutions, whether informal or formal in order to promote cooperation. Finally, the fourth criterion is more people-oriented and looks at the emergence of a specific (IV) cross-border identity, a sense of togetherness. This paper will apply these four criteria to Point Roberts in order to question its cross-border dimension and its relationship to the border and to the other side.

This theoretical framework would be incomplete without adding the contextual framework, which adds to the specificity of this border community: that of the CanadaUS border. Known for the most part of its existence as the longest undefended border in the world, this border was shaped by a long-standing tradition of openness, cooperation and cross-border interactions (Lyebecker 2018, 535; Nicol 2012, 139). As a consequence, a number of border communities have developed countless ties across the international boundary: with "cross-border families" living on both sides of the border (Lyebecker 2018, 535; Poitras 2011; Hataley \& Mason 2018, 436), with services shared across the international line, especially in rural regions (Poitras 2011; Lasserre 2012), and more generally with a great deal of cooperation on common issues (Brunet-Jailly 2008, Cappellano \& Makkonen 2020). These many linkages have led to communities that are highly integrated across the border, to such an extent that the border becomes a mere "administrative inconvenience" (Drache 2004) or just a "ditch" (BaxterMoore \& Eagles 2016).

A number of authors have also shown that these interactions have nurtured a "common identity" on both sides of the border (Nicol 2012, 139). Studying Windsor at the beginning of the 20th century, Dimmel argued that the city had a "unique transnational identity" based on joint celebration holidays, cross-border commuting, cross-border education and a strong sporting relationship (Dimmel 2001, 200-201). In other words, culturally and economically, Detroit and Windsor were "one". Hataley and Mason demonstrated a similar "collective cross-border identity" between Stanstead, Quebec, and Derby Line, Vermont, based on tremendous and diverse interactions, on political cooperation, on the existence of cross-border networks, on shared services and on cultural similarities. All these factors contribute to building a cohesive cross-border community (Hataley \& Mason 2018, 435, 436). Similarly, Richardson showed that cross-border interactions such as shopping, recreation, the relocation of Canadian firms on the American side and so on were part of the fabric that made Cascadia a cross-border region (Richardson 1998). The only major border towns that look on paper like "the perfect border town twin cities" but that are actually rather turning their backs on each other are Niagara Falls, New York, and Niagara Falls, Ontario. Although they appear to constitute a "united urban area", have the same size and speak the same language, they "do not have the social intercourse that 
could be expected from twins" and seem to be "living apart together" (Buursink 2001, 10). Interactions are rare in terms of cross-border shopping or cross-border cooperation (Baxter-Moore \& Eagles 2016; Buursink 2001, 12).

However, border towns were thrown in a new paradigm 20 years ago. Indeed, the 9/11 attacks and the ensuing homeland security policy put in place by the US to respond to the attacks led to a "hardening" or a "thickening" of the border (Lyebecker 2018, 53; Andreas \& Biersteker 2003; Alden 2008). The deployment of a myriad of security measures has made the Canada-US border less flexible and less open than it used to be, which has had an impact on cross-border trade (Globerman \& Storer 2009) and cross-border travel (Baxter-More \& Eagles 2016; Beylier 2016), while at the same time giving rise to a new "border culture" based on security (Konrad \& Nicol 2008). In other words, it has impacted the cross-border linkages that had developed over decades across this peaceful border. More importantly, it has altered the borderland identity, giving primacy to security and hampering mobility and social interactions (Konrad 2014, 49).

\section{Methodology}

This study of Point Roberts is part of a broader project on practices and representations of the Canada-US border that the author conducted in the wider Cascadia region in the fall of 2019. It combines two major research methods: an online survey that aimed at assessing people's interactions with the border, and a series of semi-directed interviews with some of Point Roberts' stakeholders. The survey was posted on many community groups on Facebook that were identified by the author based on the places where their members live. A total of 81 responses were gathered on the part of Point Roberts residents. Among the respondents, $61 \%$ were women and $38 \%$ were men, ranging in age as follows: $6 \%$ between 18 and $35,7 \%$ between 35 and 50, 42\% between 50 and 65 and $45 \%$ over 65, which mirrors the demographic profile of the community (Census Reporter 2019).

In addition to those responses, the author also took into account the responses that identified Point Roberts as the place they "go to when crossing the border". Including the responses of people that mentioned Point Roberts as their destination, as opposed to just the responses of those who are from there, offers a better understanding of the border town's cross-border links.

The survey consisted of fifteen closed-ended questions with choices involving gender, age, country of residence, distance from the border, frequency of border crossing, reasons for crossing the border, being a member (or not) of Trusted Traveler Programs, the presence of a cross-border identity and feelings of territorial attachment. It also included seven open-ended questions that pertained to the places they live, the places they go to when crossing the border, how they perceive the border, the manifestation of a cross-border identity, as well as explanations if they do not cross the border or if they have been crossing it less frequently. As a result, the survey provided the author with both qualitative and quantitative data.

Finally, the author conducted nine interviews with different residents who play a prominent role in the community: members of different associations, two businesswomen, a journalist, the current US Customs and Border Protection (CBP) Port Director and a fire fighter, all identities confidential. These interviews were semi-guided: all of the interviewees were asked the same questions that had been prepared in advance pertaining to their perception of the border, the ways in which they interact with it and the role the border plays within the community. Some additional questions were asked when clarification was needed or when the author wanted more details on specific topics. These interviews complement the qualitative dimension of the study, allowing the author to share the point of view of some of the most important stakeholders in Point Roberts regarding cross-border life. For this research, the author also conducted in 2019 interviews with Vancouver Airport Director, Gerry Bruno; a spokesperson with the Washington State Department of Transportation; and historian Mark Swenson.

\section{Analysis}

As mentioned above, border cities are traditionally on the periphery of their country and they initially developed by turning their backs on the border (Buursink 2001, 9). As far as Point Roberts is concerned, if the first statement is true, the town has always been turned towards, and dependent on, the border, because of its location as an exclave. More importantly, the border has historically played a central part in the history of the community. It is what historian Mark Swenson highlights: "the border defines and makes Point Roberts unique" (2017, 7). Often described as a natural "gated community", because you have to go through border controls before entering the territory of the town, Point Roberts has been surely shaped by its relationship with the border, which is inescapable.

\section{(I) The Morphology of Point Roberts}

Considering the first criterion that is found in theoretical models about (cross) border towns, one can note that, in terms of proximity, Point Roberts' configuration makes it a town that is not only close to but also at the border, with the farthest point from the Port of Entry (PoE), Lilly Point only 3.5 miles away from it. On a satellite image, the urban fabric shows continuity across the border (Figure 1), especially in Maple Beach, the oldest neighborhood (Swenson 2017, 343) in the northeastern part of the town (Figure 1b). Maple Beach follows the same street organization as the neighborhood across the border in Delta, Boundary Bay, and the 49th parallel is not visible in terms of break. Only boundary markers along the 


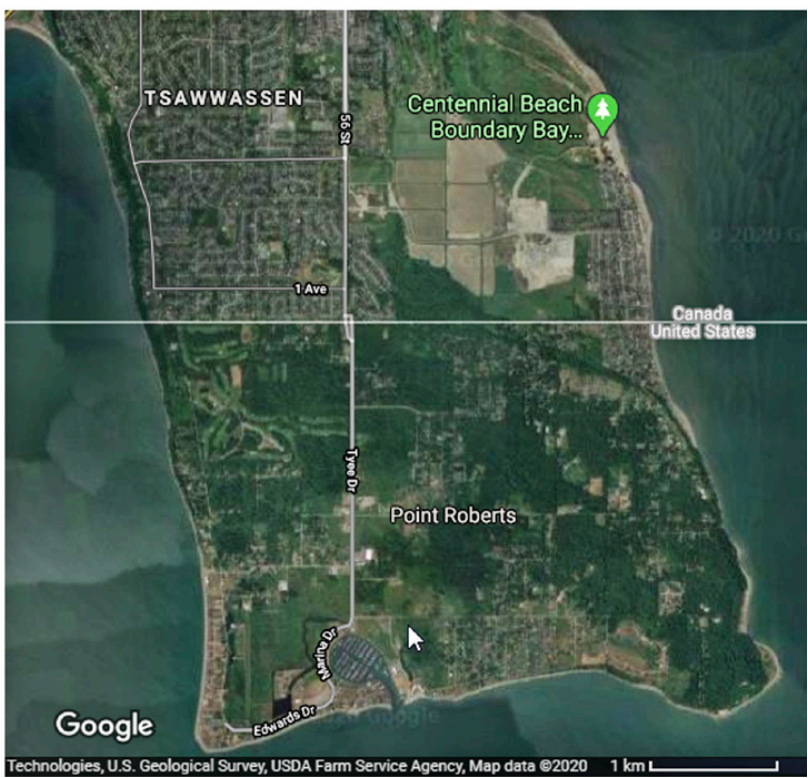

Figure 1. Point Roberts/Tsawwassen-Delta satellite map view. Source: Google Maps. street mark the border in the eastern part of the exclave, and the border crossing itself. It is important however to nuance this point because the difference highlighted in the introduction regarding the density of population is also visible from the sky, the Canadian side being more densely populated than the American side. And this difference is due to the border: when plumbing and tapped water arrived in Point Roberts in the 1980s, strict regulations were put in place to prevent uncontrolled urban development. As Swenson emphasizes, "were it not for the border, Point Roberts would be as developed as Tsawwassen, fully built out" (Swenson 2017, 383).

Then, Reitel proposed an indicator to further assess this continuity in terms of connectivity with the presence of several roads (Reitel 2013-243). Since there is only one road that crosses the border and one PoE in Point Roberts, one might assume a lack of connectivity. And yet, it does not prevent Point Roberts from being the sixth busiest border crossing in terms of vehicles and the third in terms of pedestrians along the entire Canada-US border (Table 1).

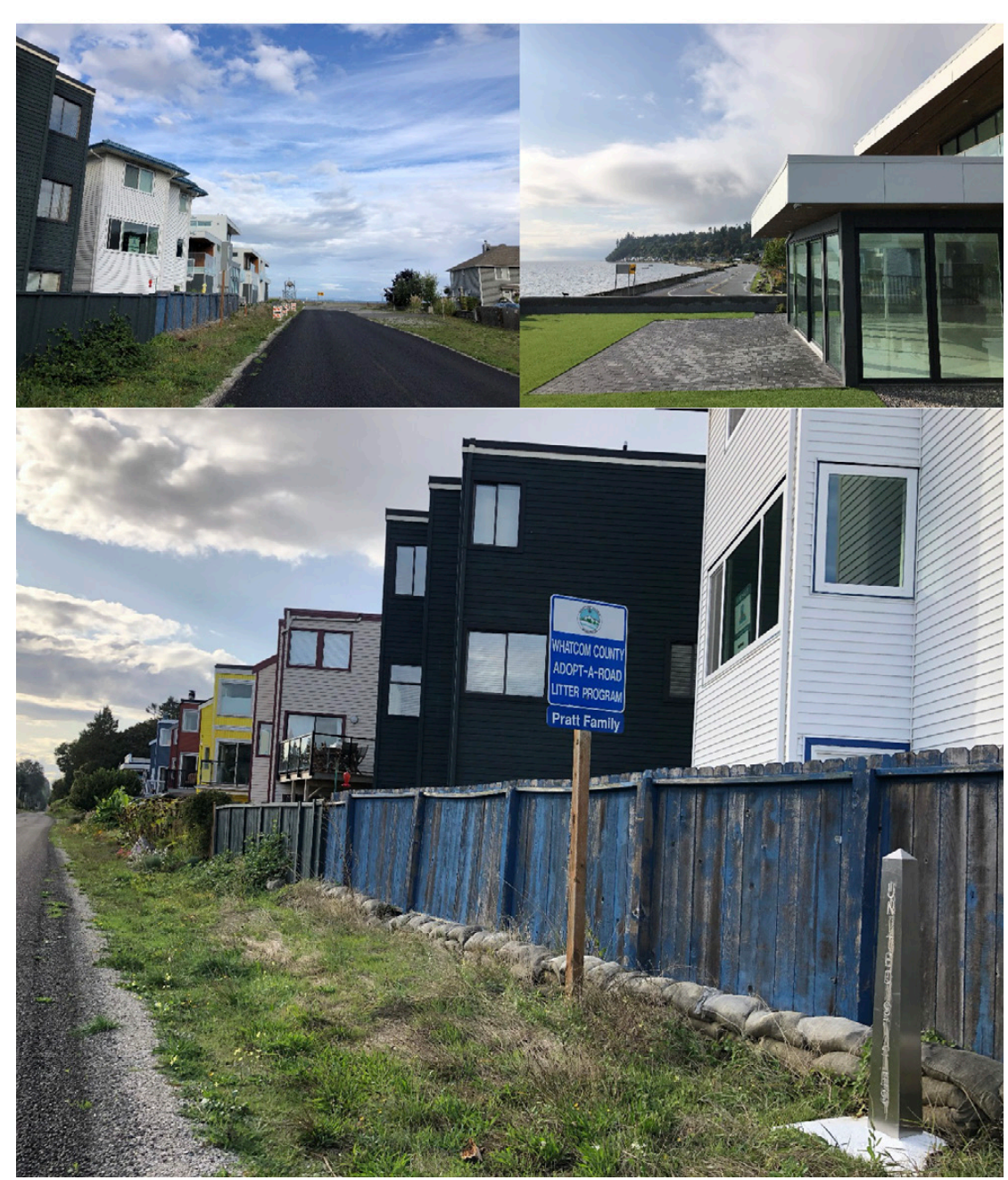

Figure 1b. Maple Beach. Pictured from the US side (pictures 1 and 3 ) and from the Canadian side (picture 2). Photo credit: author.
The third morphological element that is worth analyzing is the impact that the border has on the urban structure of the town. Studying Ciudad Juarez, a Mexican city at the Mexico-US border, Fuentes demonstrated how "the transborder interurban relationship and local needs determine the intra-urban space by influencing the location of economic [and residential] activities" (Fuentes 2000, 26). He states that businesses and residential housing compete for locations close to the border, driving up prices and exacerbating inequalities (28). This border effect is even more present in smaller territories, where options are limited. Similarly, Point Roberts' urban layout is determined by cross-border links. One can note a "specialization" of some districts located near the PoE with pick-up services Point to Point Parcel and In Out Parcel located respectively 0.2 and 0.3 miles away from the PoE on Tyee Street. The district situated at the crossroads between Tyee and Gulf Road and Tyee and Benson Road, one mile away from the PoE, concentrates the services that Canadian visitors cross the border to access, as will be discussed below, with four gas stations, a supermarket called The International Market Place, and two other pick-up services. Finally, down 
Borders in Globalization Review | Volume 2 | Issue 2 | Spring/Summer 2021 Beylier, "Cross-border Life in an American Exclave: Point Roberts and the Canada-US Border"

Table 1. Border crossings ranked by number of vehicles and pedestrians (2019). Source: US Bureau of Transportation Statistics, 2020.

\begin{tabular}{|c|l|c|c|l|c|}
\hline Rank & Port name & No. of vehicles & Rank & Port name & No. of pedestrians \\
\hline 1 & Buffalo-Niagara Falls & 4857694 & 1 & Buffalo-Niagara Falls & 384676 \\
\hline 2 & Detroit & 4474933 & 2 & Sumas & 60125 \\
\hline 3 & Blaine & 3961462 & 3 & Point Roberts & 27992 \\
\hline 4 & Port Huron & 1461765 & 4 & International Falls-Ranier & 9837 \\
\hline 5 & Champlain-Rouses Point & 1018162 & 5 & Calais & 7565 \\
\hline 6 & Point Roberts & 958558 & 6 & Oroville & 4867 \\
\hline 7 & Sumas & 880346 & 7 & Port Huron & 4416 \\
\hline 8 & Massena & 872880 & 8 & Champlain-Rouses Point & 4102 \\
\hline 9 & Calais & 664385 & 9 & Sweetgrass & 3153 \\
\hline 10 & Sault Sainte Marie & 656760 & 10 & Eastport & 2652 \\
\hline
\end{tabular}

Gulf Road, one can find a bar, Kinisky Reef's Tavern, and a café, Saltwater Café. Proximity to the border, as well as a very strict zoning code, defined the location of these businesses. In other words, to paraphrase Fuentes, the "urban function" of Point Roberts is deeply influenced by the border (2000, 32).

However, in addition to this positive "border effect", the 49th parallel also has a negative "spatial effect", if we stretch Fuentes' theory a bit, in that the border inhibits some activities by the regulations it entails. The interviewees underscored four border-related problems. The first one has to do with the hiring of staff, as emphasized by six of the eight interviewees, among whom two business owners. Because of its small size and its demographics, Point Roberts does not have a significant workforce especially for restaurants and bars. On top of that, businesses cannot hire Canadians. There was a memorandum of understanding that allowed businesses to hire "seasonal temporary workers" from Canada but it was canceled after 9/11:

There was a provision that allowed seasonal workers to come across from Canada to work in Point Roberts and [because of] the tightening down on the border and the consolidation of the treat-everybody-the-same (...) they weren't allowing seasonal workers [any more] (...). That shut down the ability of the restaurants to bring people in during the peak season (Interview resident 4, 2019).

Three residents directly blame the border for their labor challenges: "the border keeps us from hiring Canadians" (Interview resident 3, 2019); "the border is that impermeable barrier there" (Interview resident 4, 2019); "there are a lot of challenges running a business here. The border is one of them" (Interview resident 1, business owner, 2019). There is still the possibility to apply for a work visa but the process is long, up to six months, and lacks flexibility for businesses that cannot plan that far in advance (Interview resident 2, business owner, 2019). Even getting volunteers for associations such as the Food Co-Op is a hassle, and people get stopped at the border (Interview resident 3, 2019).

The second border-related problem that the community faces is a lack of affordable housing. The border and the situation of Point Roberts as a small exclave induce competition for land use. This further impacts businesses in that, if they were to find someone from continental US to work in Point Roberts, they would not be able to find affordable housing in Point Roberts. Commuting from continental US is not an option as it is one and a half hours from Bellingham, the closest major American city, with two international borders to cross. It also impacts the attractiveness of the community, especially for families or single people in their 30s who cannot afford to move to Point Roberts (Interview resident 1, 2019; Interview resident 2, 2019; Interview resident 4, 2019).

This lack of staff combined with the lack of affordable housing has an impact on businesses: "part of the problem is like last year in the summer, I only opened five days a week. I didn't open up five days a week because of lack of business. I opened up five days a week because of lack of employees" (Interview resident 2, 2019). The situation even forced two restaurants to close down: "And [if] the restaurants could stay open longer, there would be more restaurants-we've lost to two big ones-Boosters and TJs-because they couldn't get help-and [there would be] more businesses in general tourism-related things" (Interview resident 4, 2019). 
Because of zoning rules and the competition for space, another problem is the lack of hotels, which further inhibits businesses and the development of the town. As pointed out by one of the interviewees, having even a small 16-room hotel could benefit the community in terms of tourism-related activities by stimulating other businesses. It would also have a snowball effect in terms of revenue because potential visitors would pay the lodging tax, which would then be re-infused in the community and help it develop new infrastructure (Interview resident 2, 2019; Interview resident 5, 2019).

Finally, the presence of the border means that Point Roberts residents cannot get some services. Some companies such as Home Depot or Lowes do not deliver in Point Roberts, and bars and restaurants only get food and drinks twice a week in the summer and once a week in the winter (Interview resident 2, 2019). Some social services provided by Whatcom County, such as Home Care, are not available in the community (Interview resident 4, 2019; Interview resident 6,2019$)$. Children can only go to school in Point Roberts until third grade, when they are eight years old. When they are older they have to either enroll in a school in Canada or commute to the US mainland, to Blaine, the closest American city where they can go to school, crossing the border twice (Interview resident 7, 2019). Other services such as electrical work and medical aid are difficult to access as well. As one resident put it:

The border (...) is a challenge in ways that, I think, may be a little unexpected (...) because we're so isolated, we don't get a lot of the services that we would if we were on the other side (Interview resident 4, 2019).

These are rather indirect morphological problems that are entailed, some only partly, by the border combined with the fact that Point Roberts is an exclave. As noted, zoning regulations also play a part. But the problems show that the border impacts the fabric and the shape of the community, the "urban function" of Point Roberts to paraphrase Fuentes (2000, 37): some services, some businesses are inhibited by border-related regulations that prevent the development of some border-related activities that would benefit the town's economy. The border has thus a kind of "sterilizing" effect (Pradeau 1994, 227) for Point Roberts, which is, at the same time, heavily dependent on the border. This dual dimension of the border creates opportunities but also represents a source of vulnerability, placing the community in a paradoxical situation, as emphasized by Point Roberts' historian: "Our border plays an important role in our economy, an economy that serves the economy of the visitors but not the community" (Interview with Mark Swenson, 2019). The businesswomen that were interviewed similarly pointed out their dependence on Canadians, saying that between 75 and $80 \%$ of their customers were Canadians (Interview resident 2, 2019, Interview resident 1, 2019). This economic dependence is mirrored by the links that tie Point Roberts with Delta across the border, thus structuring between the two a dynamic functional relationship.

\section{(II) A Functional Border Community}

Because of the geographical situation, residents have little choice but to lead transnational lives. The survey and the interviews have shown that the lives of Point Roberts residents are "rooted on both sides of the border", to borrow an expression used in the context of US-Mexico border communities (Dear 2013, 101) thus nourishing flows that contribute to some kind of functional integration between Point Roberts and Delta. Examining cross-border flows will help us assess the ways in which Point Roberts and Delta constitute what Letniwska-Swiat calls a "crossborder functional region" in that it is defined by people's practices (Letniwska-Swiat 2002, 113).

In the case of Point Roberts, the border is heavily "practiced" both from a quantitative perspective and from a qualitative perspective. The first quantitative indicator in the survey concerns the frequency at which residents cross the border. In response to the question "how often do you cross the border?", a majority of residents (85\%) indicated that they cross it on a regular basis either once a day (26\%) or several times a week (59\%) (Figure 2). In other words, interactions with the border are a part of people's daily lives.

Qualitatively, the survey asked respondents the reasons why they cross the border (several responses could be given) (Figure 3). The top two reasons identified by Point Roberts residents are shopping (62 responses) and visiting friends and family (53), followed by recreation (35) and work (13). These activities encompass different aspects of daily life but, more importantly, they mirror the lack of options that Point Roberts has to offer in terms of shopping, work and, because of the relatively small size of the community, social interactions.

However, these numbers do not mean that Point Roberts residents go to Canada for all these activities. A more thorough analysis shows that in a majority of cases $(67 \%)$ people either go to Delta or Vancouver, respectively 44 and $23 \%$, whereas in $33.5 \%$ of cases people go to either Bellingham, or to a lesser extent, Blaine. Bellingham, the seat of Whatcom County, constitutes the closest larger city on the American side, with over 90,000 inhabitants,

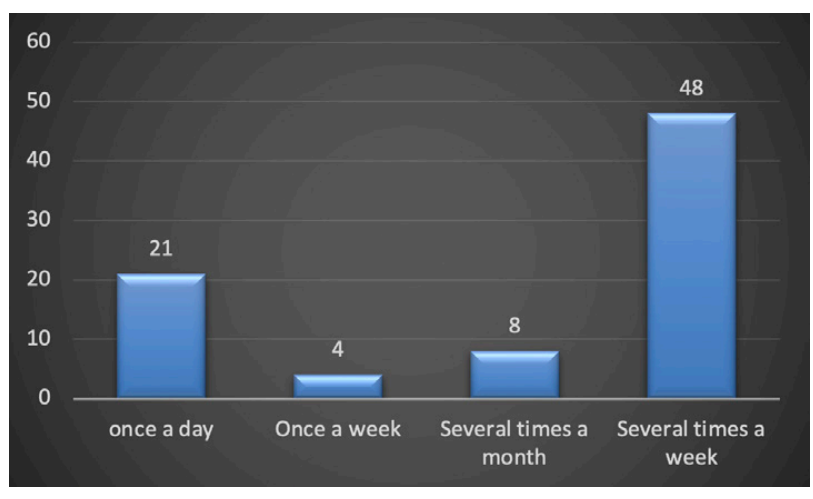

Figure 2. Frequency at which Point Roberts' residents cross border, in number of responses (81 total). Source: online survey 2019. 


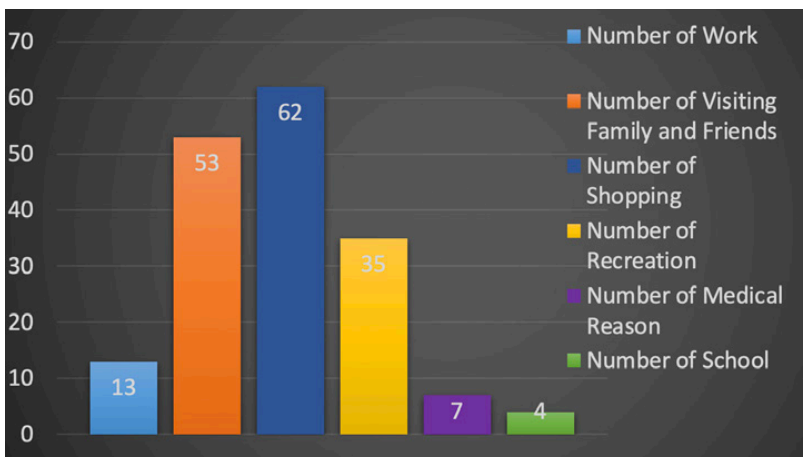

Figure 3: Reasons for Crossing the Border (Point Roberts Residents). Source: online survey 2019.

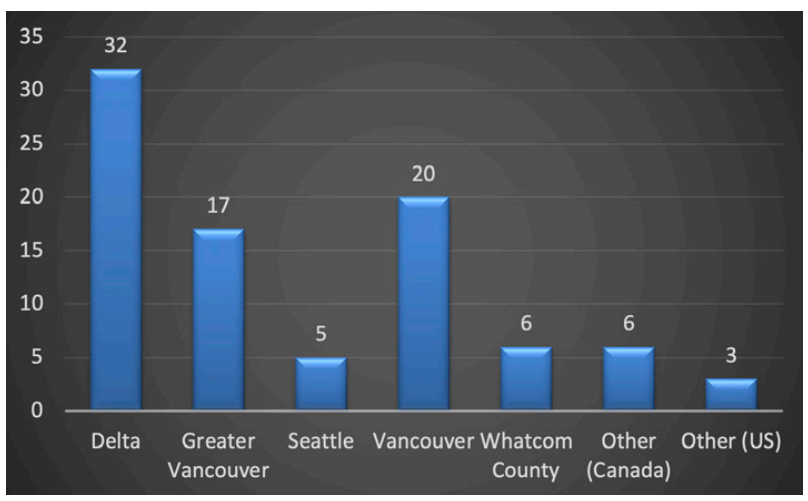

Figure 4. Origins of the people that identified Point Roberts as their destination, in number of responses (out of 89 ). Source: online survey 2019.

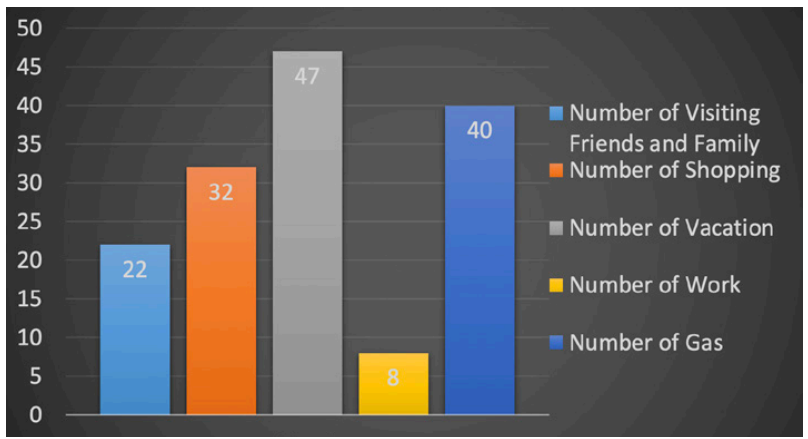

Figure 5: Reasons for crossing of the people that identified Point Roberts as their destination. Source: online survey 2019.

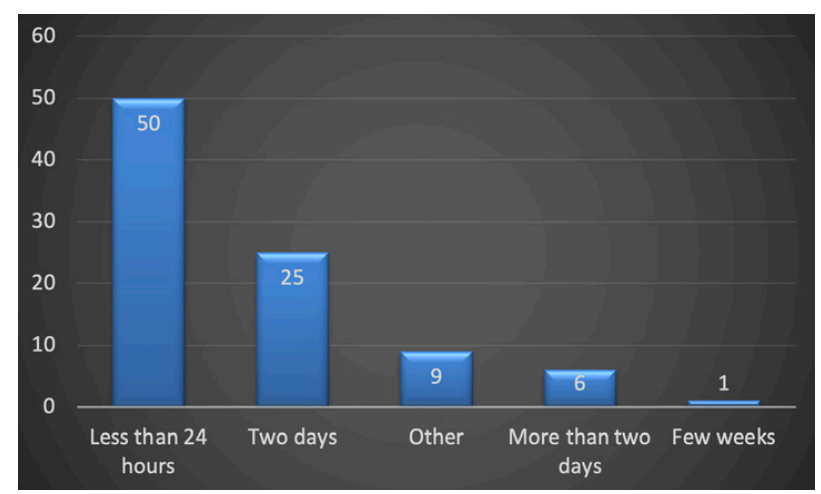

Figure 6. Duration of stay for the people that identified Point Roberts as their destination, in number of responses (out of 91). Source: online survey 2019. where most people can go shopping in major department stores or supermarkets. These patterns are in keeping with what the residents mentioned during the interviews, most of them crossing the border several times a week, some crossing it two thirds of the time to go to Canada and one third to go to the US mainland while others half and half.

Interestingly, $93 \%$ of the people surveyed cross the border for day trips, less than 24 hours, what Macias calls "excursionists" as opposed to tourists, who cross the border for more than 24 hours (2007). Added to the frequency at which Point Roberts residents cross the border, it can be argued that the 49th parallel plays a central part in people's daily lives, which are substantially cross-border.

When analyzing cross-border flows, it is also helpful to look at the respondents in the Cascadia regional survey that identified Point Roberts as the "place they go to when crossing the border". In the sample of 1,500 respondents, 91 people did so. In terms of their place of origin, one can note some great diversity as summarized in Figure 4: 84\% come from Canada, Delta being the number one origin (35\%), followed by Vancouver (22.5\%) and other cities in the Greater Vancouver area (19\%), while 16\% come from the US, $6 \%$ from Whatcom County and 5.6\% coming from Seattle. What those numbers mirror is the fact that although playing a role for local communities-namely $75 \%$ of people coming to Point Roberts live less than 25 miles from the border, among whom $20 \%$ are living less than 2 miles-the border also exerts a huge power of attraction insofar as $25 \%$ of the people coming to Point Roberts are from distant places, over 25 miles away from the border and in some cases, such as Seattle, over 100 miles away. So, it shows that the border determines flows at different scales, local and regional, both in Canada and in the US mainland.

In terms of reasons for crossing the border at Point Roberts, one can note a similar diversity. The two main reasons why people are coming to Point Roberts are either for vacation (47 responses) or for gasoline (40). Shopping (32 responses) and visiting friends and family (22 responses) constitute the other motivations for people to cross the border (Figure 5). As emphasized during the interviews, Point Roberts is known for attracting Canadians who own cabins in the exclave and stay there during the summer or who come to fill up on gas or pick up a parcel, two activities that are not limited to Point Roberts and on which other border towns such as Blaine or Sumas thrive. More generally, it is estimated that $40 \%$ of border-crossers come to Point Roberts for fuel and $26 \%$ to pick up parcels (Swenson 2017, 419). These trends are a direct result of the border effect combined with the value of the Canadian dollar: because of tax differences between the US and Canada, prices are cheaper in the US and Canadians take advantage of these differentials induced by the border. For groceries, for instance, the price differential is 30\% (Swenson 2017, 398). This constitutes an underlying force that structures these cross-border flows, making the 49th parallel "a dynamic border". As a result, "every business has both US and Canadian currency" (Interview resident 5, 
2019). What is also specific to Point Roberts compared to other border towns such as Blaine, where people cross mostly to go farther south to Bellingham, is that people cross and stay in the community (Swenson 2017, 316).

However, since their reason for crossing is mostly utilitarian, their crossing pattern differs from Point Roberts' residents (Figure 6). First of all, only half of them (50) were excursionists who cross for less than 24 hours-some even specified "less than 20 minutes"-which corresponds to people getting gas, going shopping or picking up mail, while 32 respondents were tourists coming for longer periods of time, mostly for vacation, with a majority of those owning cabins. A third category, classified in the graph as "other" gave mixed responses, saying they sometimes crossed for less than 24 hours, to get gas or go shopping, for example, and sometimes crossed for longer periods of time, in the case of vacation. Secondly, the border is not as much rooted in their daily lives as they cross the border less frequently than Point Roberts residents: most of them

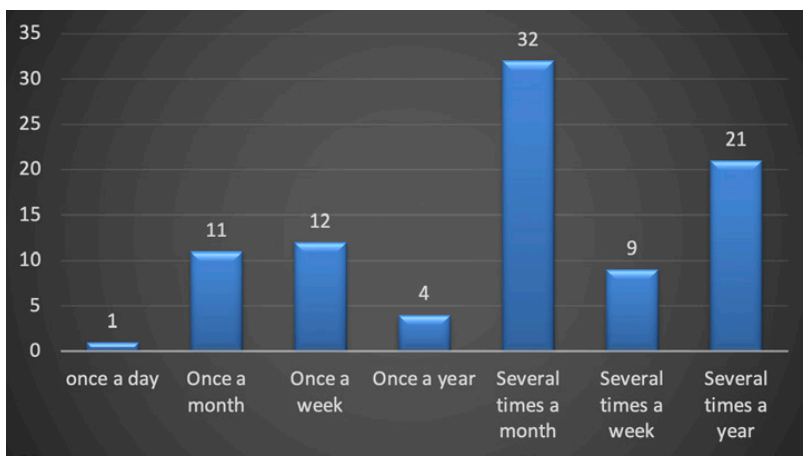

Figure 7. Crossing Frequency of the people that identified Point Roberts as their destination, in number of responses (out of 89). Source: online survey 2019.

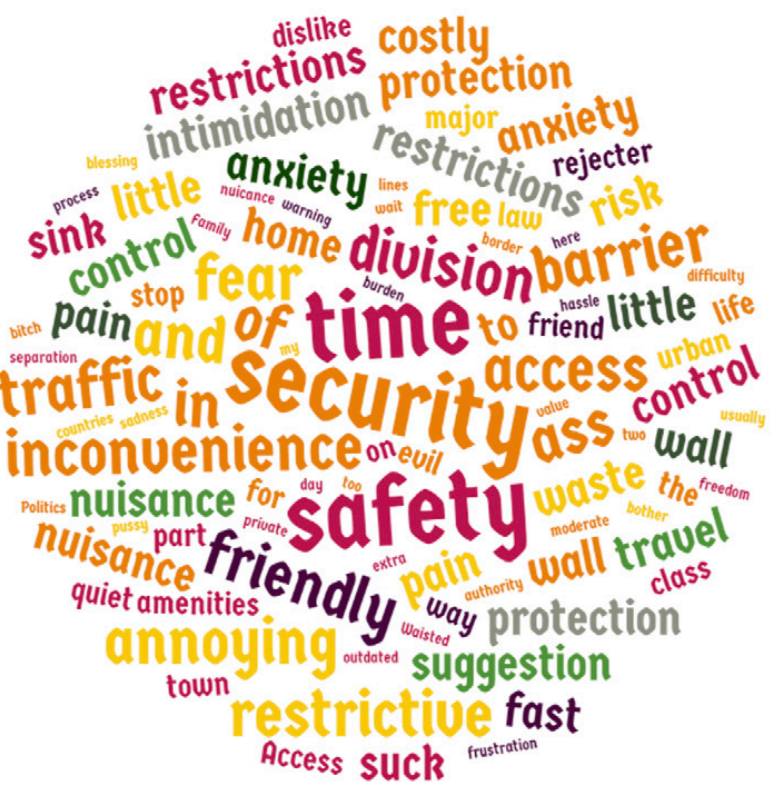

Figure 8 . Words used by Point Roberts residents to describe the border. Source: online survey 2019.
(36\%) only cross several times a month, while $23 \%$ cross several times a year and $13 \%$ once a week. One can note that the frequency that was present the most for Point Roberts-several times a week-only concerns 10\% of respondents (Figure 7). Again, these crossing patterns that are marked by lower frequency mirror their activities, mostly shopping and visiting friends and family.

These numbers indicate that the border is a dynamic interface. However, the interviews as well as one of the questions in the survey suggest that the border still represents some kind of obstacle as a result of the post-9/11 security policy implemented by the US. Referring to this new context, the interviewees describe the border as "a challenge" (Interview resident 1, 2019), "a bit of a bother" (Interview resident 3, 2019), "a slight inconvenience" (Interview resident 4, 2019). Overall, for $68 \%$ of the respondents of the survey, the border is "very visible" and for $21 \%$ it is "somewhat visible". For the majority of respondents, the border constitutes an obstacle. This fact is reflected in the words that are used to describe the border. The most frequent were "security" (10 occurrences), "time" (9), "safety" (6), the idea of a "gated community" (5), "necessary" (5), "inconvenience" (5) and only in 7th position came the idea of "access" (4) being the only positive word (Figure 8).

This situation is especially acute for businesses as emphasized above. Some pointed out the way people outside of the community were treated by border officers, who sometimes ask very intrusive questions. According to one interview respondent, several people who work in the restaurant sector have said that about half of the time they were asked what they considered "inappropriate questions" by border officers (Interview resident 1, 2019)

To mitigate the negative impact that border controls can have, the residents have put in place different strategies. First, $91 \%$ of them are Nexus members, a trusted-traveler program that was introduced in the wake of 9/11 within the framework of the "Smart Border Declaration" to expedite the crossing of the border for people who had been pre-approved after undergoing a background check (Beylier 2016, 121). Secondly, some residents highlighted the fact that the border constitutes a "time factor" (Interview resident 4, 2019) and that they "plan ahead" before crossing the border in order to avoid lines at some times of day (Interview resident 2, 2019; Interview resident 4, 2019). Finally, Point Roberts residents have tried to establish lines of communication with border agencies. Some inform the border agencies in advance when an event is going to take place so that CBP can adapt their staffing levels in order to accommodate these flows (Interview resident 2, 2019). An ad hoc Border Committee was also established a few years ago between members of the community and the CBP Port Director who meet quarterly to discuss some of the challenges that people can encounter at the border (Interview resident 3, 2019; Interview CBP, 2019). The Taxpayers' Association also set up a newsletter through which, among other things, they 
inform the residents about changing regulations at the border, regarding, for example, prohibited items (Interview resident 4,2019$)$. The goal of these initiatives is to raise awareness of the border both among the community and among CBP. Finally, in order to accommodate cross-border traffic, CBP increased its staffing levels between 2017 and 2019 from 17 officers to 24 while also adjusting schedules (Interview CBP, 2019).

\section{(III) Cross-Border Governance}

While cross-border interactions are numerous, few institutional links have developed between Point Roberts and Delta, testifying to a more general phenomenon in North America: the "limited institutionalization" of cross-border relations as compared to Europe (Sohn \& Lara-Valencia 2013, 5). Other border cities, such as Blaine or Sumas, testify to a similar lack of cross-border cooperation at the city scale as well as that of chambers of commerce.

Nevertheless, some specific cross-border agreements exist in terms of services. For instance, Point Roberts used to get its electricity and is still getting its water from Canada (Interview resident 3, 2019). Firefighters have also been working with Canadian volunteers for close to 30 years because the demographics of the community proves insufficient to provide people (Interview resident $6,2019)$. One instance of cross-border cooperation is particularly worth analyzing. As a response to a project of building AM radio towers in 2012 in Point Roberts, the residents of both Point Roberts and Delta created the Cross-Border Coalition, an association, which launched a legal battle to prevent the construction of these towers. They eventually managed to prevail in March 2015 and

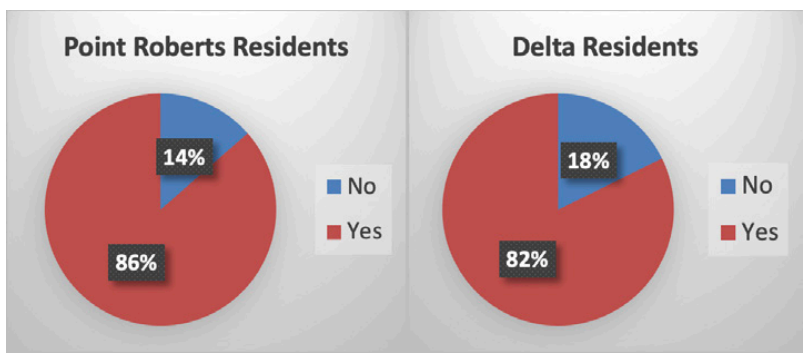

Figure 9. Answers to the question "Would you say you belong to a cross-border region?” Source: online survey 2019.

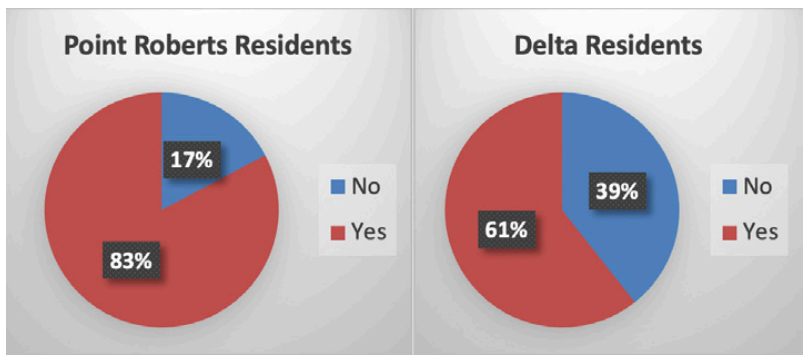

Figure 10. Answers to the question "Do you think you share a common identity with the people living across the border?” Source: online survey 2019. the towers were never built (Interview resident 4, 2019; Swenson 2017, 18, 30). The Point Roberts Marina has also developed relationships with 80-some marinas between the US and Canada, but the connections are more about communication and no working arrangement has been signed to deepen these relations (Interview resident 5, 2019).

As a consequence, one can say that the functional relationship that links Point Roberts with Delta across the border, although very dynamic, has yet to lead to formal cross-border cooperation. Contacts remain informal in shape and limited in numbers. One exception, however, is important to note: although Point Roberts does not have a sister city agreement with Delta, it does with Campobello, New Brunswick, a Canadian exclave on the far east of the border, one of the goals of this agreement being to lobby governments to create a policy provision for exclaves (Swenson 2017, 404).

\section{(IV) Identity}

Finally, since borders can "define and produce a regional identity" (Giffinger \& Hamedinger 2013, 207), the last criterion that is worth examining is the presence or the absence of some kind of cross-border identity that can be shared between Point Roberts and Delta. It is what Buursink calls a "feeling of togetherness" or what Herzog describes as a "transboundary social system and a community of interests” (Herzog 1990).

The last section of the survey had to do with this topic. People were asked if they felt they belonged to a cross-border region. As illustrated in Figure 9, similar proportions of the respondents from Point Roberts and Delta answered that they do belong to a cross-border region: between 82 and $86 \%$. For many residents, proximity to the border, the necessity of crossing it and the economic dependence of the community on Canada define Point Roberts as a cross-border region. Likewise, Delta residents highlight similar reasons, pointing out the numerous cross-border trips that people make.

However, this belonging does not necessarily translate into the presence of a cross-border identity on both sides of the border. For respondents in Point Roberts, it does since $83 \%$ of them answered positively whereas only $61 \%$ of respondents in Delta gave a similar response (Figure 10).

This contrast is even more telling when people were asked about which scale of community they feel the most attached to (Figure 11). In Point Roberts, $23 \%$ of the sample first identify with a cross-border region while a majority (41\%) identify with their country. For Delta, only $6 \%$ identify with Cascadia while a huge majority (60\%) predominantly identify to Canada first.

A factor that could foster this emerging cross-border identity is the presence of a cross-border newspaper, the All Point Bulletin, a local newspaper founded in 1985. Even 
if it mainly deals with Point Roberts, in order to "diffuse our message and the significance of our newspaper [which] is all about being local", close to half of its copies are distributed in Tsawwassen and Ladner (over 4,000 out of 9,000 copies) (Interview resident 7, 2019).

Interestingly, $19 \%$ of people feel a deep attachment to Point Roberts first, on the American side. This "sense of community" permeated the interviews as well. One resident emphasized the fact that Point Roberts is "very community oriented" (Interview resident 4, 2019) as evidenced by the presence of associations that defend the interests of the community such as the Circle of Care, the Voters' Association, the Taxpayers' Association, and the Point Interface, which is a mailing list to inform people about local issues and events. It is also important to underscore that the Taxpayers' Association, although not a cross-border institution per se, was created "to give them [Canadians] a voice" (Interview resident 4, 2019).

The different interviews also highlighted specific characteristics of Point Roberts such as its quality of life based on safety, tranquility and a low crime rate; the crime rate is $63 \%$ lower than the national average and $72 \%$ lower than Washington State's average (Swenson 2017, 317). Four interviewees compared Point Roberts to a gated community. This feeling of protection is attributed to the border as summed up by one resident: "The safety and the security that we feel is because the guards have guns, as we are behind a gate of sorts" (Interview resident 4, 2019). It was even compared to "going back to the 70s" by three interviewees. All these characteristics impart to the place a kind of uniqueness that people in Point Roberts frequently underscore. And the border no doubt contributes to this uniqueness and to the specificity of the community:

It [the border] dominates our lives. It's there all the time. You always know about it. All sorts of benefits come with it. It turns Point Roberts into a gated community. It keeps us from being turned into strip malls that are Tsawwassen. It makes it safe as a community, literally the safest community in North America (Interview resident 4, 2019).

\section{Discussion}

What the survey and the interviews have shown is that Point Roberts evinces a great "level of connectivity" to Delta, an expression borrowed from Reitel for whom connectivity is a defining feature of border towns (Reitel 2013, 245). Three of the four criteria proposed to define border towns were found to be present.

Firstly, morphologically (I), the border connects Point Roberts to Delta, but it also defines its urban space, and not always for the better. Indeed, the combination of Point Roberts' geographic situation as an exclave and the presence of the border affects Point Roberts' "territorial capital" defined as "different area-bounded factors that
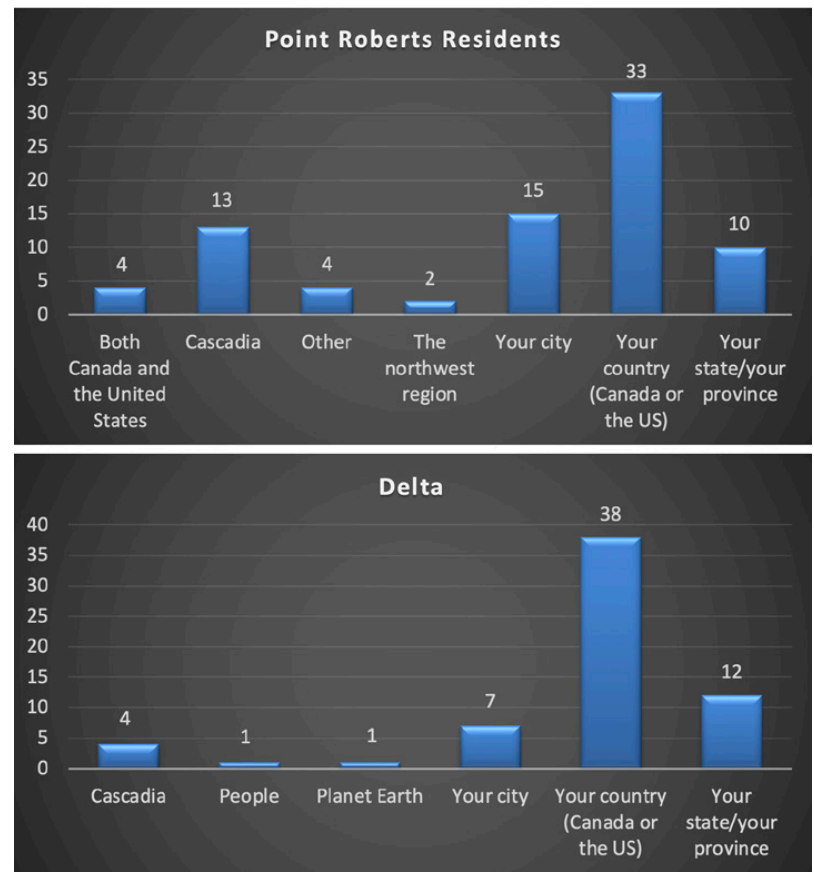

Figure 11. Answers to the question "To which of the following do you feel more attached to?” Source: online survey 2019.

cause some regions to be more competitive than others" (Ginffinger 2013, 207). It constitutes a handicap (Reitel \& Zander 2020) and it can be sterilizing (Pradeau 1994, 227). Addressing some of these challenges could help "turn the scar it represents into a resource" (Amilhat-Szary 2015, 85). Exploiting the benefits that the border constitutes would mean, according to some interviewees, having access to the money the border generates in terms of gas money, which finds itself on a Border Transport Benefit Fund to which Point Roberts rarely has access, and in terms of destination tax from the parcel industry, which a lack of transparency makes it hard to assess (Interview resident 3, 2019; Interview resident 4, 2019). These funds could allow Point Roberts to fund a ferry to the mainland as was planned in the 1990s (Swenson 2017, 393) and thus develop accessibility by lessening the residents' dependence on the border.

Then, functionally (II), the border is heavily practiced by local residents, although more by Americans than by Canadians, who use it for utilitarian purposes. Point Roberts' relations are polarized by the border, whereas Canadian residents have access to a vast area-Greater Vancouverthat diversifies their practices and undermines the power of attraction exerted by the border. It still means that it is the location of a great number of cross-border ties, which bind Point Roberts and Delta, defining a "cross-border functional region" (Letniwska-Swiat 2002, 113). The border structures multi-scalar flows, which impart to Point Roberts a level of importance not only locally but also regionally, encompassing a large part of Cascadia.

From an identity (IV) perspective, the survey has shown that residents feel that they live in a cross-border region 
while, at the same time, sharing, to some extent, a common binational identity with people across the border. That being said, when asked about the manifestation of this cross-border identity, the respondents gave reasons that were the same as those given for the manifestation of the cross-border region: similar language and common values, cross-border interactions and having friends and/or family in the other country. In other words, they did not necessarily distinguish the existence of a cross-border region from that of a cross-border identity and rather defined both as a result of the functional links that bind both sides of the border. In addition, Americans felt a stronger cross-border identityalthough not that prominent in that it rarely prevailed over attachment to country-than Canadians, pointing out an imbalance of feelings of belonging between the two sides of the border.

Finally, as far as cross-governance (III) is concerned, there are very few institutional links between Point Roberts and Delta. Even if some resident-based organizations were created, they never developed into something more official. As often the case between Canada and the US, cooperation is rather informal and/or temporary. On the scale of federal governments, for instance, one can note that the agreements that dealt with the border-whether the Smart Border Declaration or the Beyond the Border Agreementdid not lead to the creation of any cross-border institutions. The Beyond the Border Agreement created a Beyond the Border Steering Committee that disbanded when governments changed (Interview G. Bruno, 2019).

All in all, three out of the four criteria that define a border town are significantly present, pointing to incomplete integration. Besides, from a functional perspective and an identity perspective, cross-border integration is much stronger on the American side than on the Canadian side. Because Point Roberts is an exclave, one can talk about forced, amplified and asymmetrical integration. It is also important to note that some of the cross-border interactions that happen in Point Roberts are not "cross-border" per se insofar as some people are crossing the border to go to the US mainland. Point Roberts is therefore as much anchored in Canada as it is in the US. Further research should focus on identifying the actual proportions of the community's links with Canada and with the US.

\section{Conclusion}

With its unique configuration as an exclave, Point Roberts is at the center of integrational forces, which make it a cross-border community. It is not only defined by its proximity to the border but also by the links the town has developed with Delta and, to a certain extent, the Greater Vancouver area, particularly morphological, functional and cultural. The only type of cross-border connection not really present in the area has to do with institutional cooperation or cross-border governance. Point Roberts is therefore a part of a cross-border region, although asymmetrical and incomplete, shaped by cross-border links that entail interactions and interdependence between both sides, a key characteristic of border towns (Fuentes 2000).

Even if some authors argue that 9/11 has altered the "social fabric" of border regions (Konrad 2014, 49-50), the border remains a factor of connectivity in that local residents have adapted to the new security measures by enrolling in facilitation programs or by adapting their crossing behaviors. What is certain is that residents have noticed the difference and more specifically have noticed the "banalization" that the Canada-US border has experienced in the last 19 years as a result of the "one face at the border policy" (Beylier 2016, 294):

when the border got tighter after 9/11...the federal government (...) started treating all people the same, which means that anybody coming across the Point Roberts border is in theory treated exactly the way somebody's trying to come through the Mexican border (Interview resident 4, 2019).

While being the community's raison d'être, the border still represents an inescapable threat. In 2019, one resident underscored the feeling of isolation that derives from being an exclave: "We're floating off from the US. We're on our own" (Interview resident 4, 2019). This is even more true in the current context of the COVID-19 pandemic. Indeed, since March 21, 2020, the Canada-US border has been closed to all non-essential travel, thus putting in jeopardy not only the economic activity of the town, which is heavily dependent on cross-border travel, but also the lives of Point Roberts residents who are taken hostages and felt that the "community was being ripped apart" (Fremson 2020). This situation thus further amplifies Point Roberts' dependence on the border, revealing some of the major issues that need to be addressed. If solutions are not found, the future of the exclave may be put into question.

\section{Acknowledgement}

The author would like to thank the Border Policy Research Institute and Borders in Globalization for the fellowship that they awarded him to make this field trip possible. The author would also like to thank Clea Fortuné for her help with Excel and Jeff Nimmo and Alexandre Adouard for proofreading the paper.

\section{Works Cited}

\section{*All URLs last accessed May 2021.}

Alden, Edward. 2008. The Closing of the American Border. New York: HarperCollins.

Amilhat-Szary, A.L. 2015. Qu'est-ce qu'une Frontière aujourd'hui? [What is a Border Today?]. Paris: Presses Universitaires de France.

Andreas, P., and T.J. Biersteker. 2003. The Rebordering of North America: Integration and Exclusion in a New Security Context. New York: Routledge. 
Borders in Globalization Review | Volume 2 | Issue 2 | Spring/Summer 2021

Beylier, "Cross-border Life in an American Exclave: Point Roberts and the Canada-US Border"

Baxter-Moore N., and M. Eagles. 2016. "'Living Apart Together': Challenges of Urban Governance Across the Canada-US Border: the Cities of Niagara Falls", Paper presented to the biennial conference of MANECCS, Portland, ME, October 20-22.

Beylier, P.A. 2016. Canada/États-Unis: les enjeux d'une frontière. Rennes: Presses Universitaires de Rennes.

Brunet-Jailly, E. 2008. "Cascadia in Comparative Perspectives: Canada-U.S. Relations and the Emergence of Cross-Border Regions", Canadian Political Science Review 2(2 June): 104-124.

Brunet-Jailly, E. 2000. "Globalization, integration, and cross-border relations in the metropolitan area of Detroit [USA] and Windsor [Canada]", International Journal of Economic Development 2(3): 379-401.

Bucken-Knapp, G. 2001 "Just a train-ride away, but still worlds apart: Prospect for the Øresund region as a binational city", GeoJournal 54: 51-60.

Buursink, Jan. 2001. "The binational reality of border-crossing cities", GeoJournal 54: 7-19.

Cappellano F., and T. Makkonen. 2020. "The Proximity Puzzle in Cross-Border Regions”, Planning Practice \& Research 35(3): 283-301. https://doi.org/10.1080/02697459.2020.1743921

"Census Profile, 2016 Census-Delta, District municipality [Census subdivision], British Columbia and Canada [Country]", Ottawa, Statistics Canada. https://www12. statcan.gc.ca/census-recensement/2016/dp-pd/prof/ details/page.cfm?Lang=E\&Geo1=CSD\&Code1=5915011\&Geo2=PR\&Code2=01\&Data $=$ Count\&SearchText=Delta\&SearchType=Begins $\&$ SearchPR $=01 \& T A B I D=1 \& B 1=A \|$

Cold-Ravnkilde, S.M., J. Singh, and R.G. Lee. 2004. "Cascadia: The $(\mathrm{Re})$ construction of a bi-national space and its residents", Journal of Borderlands Studies 19(1): 59-77. https://doi.org/10.1 080/08865655.2004.9695617

Dear M. 2013. Why Walls Won't Work-Repairing the US-Mexico Divide. Oxford: Oxford University Press.

Dimmel, B. 2011. "'South Detroit, Canada': Isolation, Identity and the US-Canada Border, 1914-1918", Journal of Borderlands Studies 26(2): 197-209. https://doi.org/10.1080/08865655.2011 .641321

Drache, D. 2004. Borders Matter: Homeland Security and the Search for North America. Halifax: Fernwood.

Eagles, M. 2018. "At War Over the Peace Bridge. A Case Study in the Vulnerability of Binational Institutions", Journal of Borderlands Studies 35(5): 781-799. https://doi.org/10.1080/0 8865655.2018.1465354

Ehlers, Nicole. 2001. "The Utopia of the binational city", GeoJournal 54: 21-32.

Foucher, M. 1991. Fronts et Frontières. Paris: Fayard.

Fremson, R. 2020. “'I am Stuck until that border opens': Marooned in Paradise", New York Times (September 1).

Fuentes, C. 2000. "Urban Function and Its Effect on Urban Structure: The Case of Ciudad Juárez, Chihuahua", Journal of Borderlands Studies 15(2): 25-43. https://doi.org/10.1080/0886 5655.2000.9695554

Ganster, P., and K. Collins. 2017. "Binational Cooperation and Twinning: A View from the US-Mexican Border, San Diego, California and Tijuana, Baja California", Journal of Borderlands Studies 32(4): 497-511. https://doi.org/10.1080/08865655.2016.1 198582

Globerman, Stephen, and Paul Storer. 2009. "Border Security and Canadian Exports to the United States: Evidence and Policy
Implication", Canadian Public Policy-Analyse de Politiques, XXXV(2): 171-186. https://doi.org/10.3138/cpp.35.2.171

Hataley, T., and S. Mason. 2018. "Collective Efficacy Across Borders: The Case of Stanstead, Quebec and Derby Line, Vermont", Journal of Borderlands Studies 33(3): 433-444. https://doi.org/10.1080/08865655.2017.1332487

Herzog, L. 1991. "International Boundary Cities: The Debate of Transfrontier Planning in Two Border Regions", Natural Resources Journal 31(3): 587-608. https://digitalrepository. unm.edu/nrj/vol31/iss3/6

Herzog, L. 1990. "Border Commuter Workers and Transfrontier Structure Along the United States Mexico Border", The Journal of Borderlands Studies 5(2): 1-20. https://doi.org/10.1080/0886 5655.1990.9695393

Gay, J.C. 2004. Les Discontinuités spatiales. Paris: Economica.

Giffinger, R., and A. Hamedinger. 2013. "Borders in Metropolitan Development: The Case of Vienna", Journal of Borderlands Studies 28(2): 205-219. https://doi.org/10.1080/08865655.2013.854655

Jańczak, J. 2017. "Town Twinning in Europe. Understanding Manifestations and strategies", The Journal of Borderlands Studies 32(4): 477-495. https://doi.org/10.1080/08865655.2016.1267589

Kaisto, V. 2017. "City Twinning from a Grassroots Perspective: Introducing a Spatial Framework to the Study of Twin Cities", Journal of Borderlands Studies 32(4): 459-475. https://doi.org/ 10.1080/08865655.2016.1238315

Kearney, M. 1995. Border Cuates-A History of US/Mexican Twin Cities. Austin: Eakin Press.

Konrad, V. and H.N. Nicol. 2008. Beyond Walls: Reinventing the Canada-United States Borderlands. Aldershot: Ashgate Press.

Konrad, V. 2014. "Borders and Culture: Zones of Transition, Interaction and Identity in the Canada-United States Borderlands", Eurasia Border Review 5(1): 41-57. http://hdl. handle.net/2115/57845

Lasserre, Frédéric, Patrick Forest, and Enkeleda Arapi. 2012. «Politique de sécurité et villages-frontière entre États-Unis et Québec», Cybergeo: European Journal of Geography 595 (March). https://doi.org/10.4000/cybergeo.25209

Letniowska-Swiat, S. 2002. "Pratiques et perceptions d'une métropole transfrontalière : l'exemple lillois » in Reitel, Bernard et al (eds.) Villes et Frontières. Paris: Anthropos.

Lunden, T., and D. Zalamans. 2001. "Local Co-operation, Ethnic Diversity and State Territoriality-The Case of Haparanda and Tornio on the Sweden-Finland Border", GeoJournal 54: 33-42. https://doi.org/10.1023/A:1021184430515

Lyebecker, D.L., Mark K. McBeth, Adam M. Brewer, and Carine De Sy. 2018. "The Social Construction of a Border: The Canada-US Border", Journal of Borderlands Studies 33(4): 529-547. https:// doi.org/10.1080/08865655.2016.1247652

Macias, M.C. 2007. « L'Espace frontalier Mexique/États-Unis après le 11 septembre 2001 : Entre processus transfrontaliers et transnationaux », Cahiers des Amériques latines 56: 83-97. https:// doi.org/10.4000/cal.1797

Nugent, P. 2012. "Border Towns and Cities in Comparative Perspective" in M.W. Thomas and D. Hastings (ed.s) A Companion to Border Studies. Hoboken: New Jersey, Wiley Blackwell.

"Point Roberts, WA", Census Reporter. https://censusreporter. org/profiles/16000US5355015-point-robenrts-wa/

Poitras, J. 2011. Imaginary Line: Life on an Unfisnished Border. Fredericton: Goose Lane Editions. 
Borders in Globalization Review | Volume 2 | Issue 2 | Spring/Summer 2021 Beylier, "Cross-border Life in an American Exclave: Point Roberts and the Canada-US Border"

Pradeau, Christian. 1994. Jeux et enjeux des frontiers. Bordeaux: Presses Universitaires de Bordeaux.

Reitel B., and P. Zander. 2020. "Ville Frontalière", HyperGéo. http://www.hypergeo.eu/spip.php?article206

Reitel, B. 2013. "Border Temporality and Space Integration in the European Transborder Agglomeration of Basel", Journal of Borderlands Studies 28(2): 239-256. https://doi.org/10.1080/08 865655.2013.854657

Reitel, B., P. Zander, and J.L. Piermay. 2002. Villes et Frontières. Paris: Anthropos.

Renard, J.P. 2001. «Villes et frontières: antagonismes et convergences sémantiques». Hommes et Terres du Nord 2: 112-122.

Richardson, K. 1998 "What is So Enticing Over the Border?: Whatcom County, Washington, and the Greater Vancouver Area”, Canadian Journal of Regional Science 21(2): 277-293.

Smouts, M., 1998. "The Region as the New Imagined Community?" in P. Le Gal and C. Lequesne (eds.) Regions in Europe. London: Routledge.
Sohn, C., and F. Lara-Valencia. 2013. "Borders and Cities: Perspectives from North America and Europe" Journal of Borderlands Studies. 28(2): 181-190. https://doi.org/10.1080/08 865655.2013.854662

Soi, I., and P. Nugent. 2017. "Peripheral Urbanism in Africa: Border Towns and Twin Towns in Africa", Journal of Borderlands Studies 32(4): 535-556. https://doi.org/10.1080/08865655.2016.1196601

Sparrow, G. 2001. "San Diego-Tijuana: Not Quite a binational city or region", GeoJournal 54: 73-83. https://www.jstor.org/ stable/41147639

Swenson, Mark. 2017. Point Roberts Backstory-Tales, Trails and Trivias from an American Exclave. Bellingham: Village Books.

Vanneph, A. 1995. "Villes frontalières Mexique-États-Unis" in Gondard Pierre (ed.) La Frontière Mexique/États-UnisMutations économiques, sociales et territoriales. Paris: Édition de l'IHEAL. 246-259. 